\title{
Chapter 11 \\ Monitoring of Glaciers and Glacial \\ Lakes in Afghanistan
}

\author{
Sudan Bikash Maharjan, Finu Shrestha, Fayezurahman Azizi, \\ Esmatullah Joya, Birendra Bajracharya, \\ Mohammad Tayib Bromand, and Mohammad Murtaza Rahimi
}

\subsection{Introduction}

During the needs assessment in Afghanistan, the General Directorate of Water Resources (GDWR) of the National Water Affairs Regulation Authority (NWARA) (previously Water Resource Department (WRD) of the Ministry of Energy and Water (MEW)) emphasized that the compilation of comprehensive data on the glaciers in the country is a national priority.

Glaciers are of paramount importance in arid and semi-arid places like Afghanistan and serve as sources of freshwater for a large proportion of its population. Globally, the considerable evidence on retreat and shrinkage of glaciers, and the formation and expansion of glacial lakes have become a hot topic for researchers, scientists, and policymakers. The clear evidence of glacial retreat in Afghanistan, as found by ICIMOD's studies, poses a serious threat to the country's water security.

Worldwide, most glaciers have undergone major retreat since the end of the Little Ice Age (Marshall 2014; Zemp et al. 2014). This retreat was first noticed in the 1960s (Grotzbach 1964; Gilbert et al. 1969; Braslau 1972), and it accelerated in the last three decades (Gardent et al. 2014; Bajracharya et al. 2014a, b; Mernild et al. 2013). The HKH region has the highest concentration of snow and glaciers outside the polar regions and they play a pivotal role in supplying water to 10 major river basins (Bajracharya and Shrestha 2011). Glacial changes are also a valuable indicator of climate change (Wester et al. 2019; Nie et al. 2017; Song et al. 2017; Bajracharya et al. 2014a). By the end of the twenty-first century, the global surface

\footnotetext{
S. B. Maharjan $(\bowtie) \cdot$ F. Shrestha - E. Joya - B. Bajracharya · M. M. Rahimi International Centre for Integrated Mountain Development, Kathmandu, Nepal e-mail: sudan.maharjan@icimod.org; bikashsudan@gmail.com

F. Azizi · M. T. Bromand

General Directorate of Water Resources, National Water Affairs Regulation Authority, Kabul, Afghanistan

(C) The Author(s) 2021

B. Bajracharya et al. (eds.), Earth Observation Science and Applications for Risk Reduction and Enhanced Resilience in Hindu Kush Himalaya Region, https://doi.org/10.1007/978-3-030-73569-2_11
} 
temperature is likely to exceed by $1.5^{\circ} \mathrm{C}$ (IPCC 2013). In the case of Afghanistan, the reanalysis data from the period 1951 to 2010 show that the mean annual temperature increased in all parts of the country by $1.8{ }^{\circ} \mathrm{C}$, with the highest increase of $2.4{ }^{\circ} \mathrm{C}$ recorded in the south, 1.6 and $1.7{ }^{\circ} \mathrm{C}$ in north and central part of the country, and $1{ }^{\circ} \mathrm{C}$ in the Hindu Kush Region (Aich et al. 2017). It is also observed that the warming in the main glaciated region of Afghanistan (Badakhshan) is between 0.3 and $0.7^{\circ} \mathrm{C}$. Moreover, the projection of mean temperature under RCP 4.5 indicates that by the $2050 \mathrm{~s}$, the strongest warming in the country is set to take place in the Wakhan Corridor-by over $2{ }^{\circ} \mathrm{C}$ - followed by the Central Highlands -by 1.75 to $2{ }^{\circ} \mathrm{C}$ (Aich et al. 2017). This rise in temperature will obviously lead to the melting of glaciers, trigger variability in snow cover, and change the other components of the cryosphere. Further, the combination of dust storms - mainly originating from the Central Asian countries and the northern deserts of Afghanistan - and the aerosols resulting from anthropogenic activities complicate the interaction between the atmosphere and the dynamics of the glaciers (Prasad et al. 2011).

It is all too well known that changes in glaciers will have a significant impact on the water resources - it will reduce water availability and the hydropower potential and change the seasonality of flows in the region. Glacier retreats often lead to formation of glacial lakes, the expansion of existing glacial lakes, and to Glacial Lake Outburst Floods (GLOFs). In this regard, several catastrophic GLOFs have already been reported from the region (Gurung et al. 2017; Allen et al. 2015; Bajracharya et al. 2007). A recent GLOF in a tributary of Panjshir River (on 12 July 2018) not only devastated the village of Peshghor in Khenj but also dammed the Panjshir River, thereby inundating the main river valley for up to $1.7 \mathrm{~km}$ from the river confluence. This GLOF was due to the sudden release of glacial lake water from newly developed and rapidly expanded glacial lake on the surface of the glacier ice covered by debris due to melting of glacier ice and snow. The glacial lake water released through the sub-glacial channel due to melting and erosion of underneath ice and debris (Maharjan 2018; Afghanistan Times 2018; Flood List 2018). The flood took place at midnight, thereby trapping the people who were asleep. Ten people lost their lives, while there were severe damages to livestock and property - some 300 houses were swept away, over 20 villages were affected, and a market in the Peshghor area also bore the brunt (Afghanistan Times 2018). It is in such a context that the monitoring of glaciers and glacial lakes in Afghanistan gains critical importance; in-depth studies must be conducted to understand the response of glaciers to climate change and on how climate change affects the overall hydrology of the country.

In Afghanistan, glaciers serve as the headwaters of the Panj-Amu (Amu Darya) River Basin and the Kabul River Basin which contribute to the Indus river basin. However, there is very little information on the country's glacier extent and on periodic glacial changes because of the complex topography, paucity of field work, and geopolitical restrictions. This means there is not enough understanding about freshwater availability, potential glacial hazards, and future scenarios on water availability in Afghanistan. As regards addressing the gaps in information on the 
periodic changes in glaciers and glacial lakes, since 2017, ICIMOD has been working closely with the GDWR to develop the capacity of Afghan professionals in this area and to prepare detailed information on the status and changes in glaciers and glacial lakes. This collaborative research has helped to comprehend the recent (2015) and decadal (1990, 2000, and 2010) scenario of glaciers and glacial lakes; it has also generated a four-period database that would shed more light on glacial melt and glacial hazards, and thus predict the future scenario of water availability in the country.

\subsection{Glacier and Glacial Lake Monitoring Approach}

Glaciers and glacial lakes are interwoven components of the cryosphere. Glaciers are composed of snow, ice, water, and rock/debris which move slowly down the gradient and melt due to changes in temperature. Glacial lakes are formed by the impoundment of meltwater in the lowlands formed by glacier erosion and/or blocked by the glacier-deposited moraine.

In general practice, the mapping and monitoring of glaciers and glacial lakes are done either through field practices or through remote sensing. Field-based monitoring is widely practiced to gauge glacier mass changes. It also helps in gathering information about the physical characteristics of a glacial lake, its moraine dam, and other surrounding features so that the risk of GLOF is mitigated. The demarcation of the boundary of a glacier and glacial lake is conducted using various survey instruments like total stations and the differential Global Positioning System (dGPS) in the field. Although the field-based method provides more accurate information, it is only applicable in the case of a few accessible glaciers; the rest is almost inaccessible due to rugged terrain and extreme weather conditions; there's also the factor of time and resources.

Before the availability of satellite images, glaciers were mostly studied via fieldwork. A few scientists have conducted field-based studies on some of the Afghan glaciers; this was before the 1980s. In 1964, Grotzbach noted a general glacier retreat in the Khwaja Mohammed mountains; in 1969, Gilbert et al. studied a small glacier near Mir Samir in central Hindu Kush; (in 1972, Braslau) studied the general recession of the Keshnikhan glacier at the entrance to the Wakhan Corridor; in 1976, Breckle and Frey (1976a, b) noticed relatively strong glaciation in east and south-east Afghanistan near the Pakistan border; in 1974, Austrian investigators (Patzelt 1978) measured the glacier orientation, maximum and minimum elevation, length, total area and debris-covered area, glacier hypsometry, and glacier changes in the South Issik glacier; Patzelt also studied the transient snow lines, the lateral moraine altitude, and the daily ablation rates of the glacier (Haritashya et al. 2009).

In the past, field and aerial photographs were widely used to study glacial changes. The Russians were very much interested in the glaciers of Afghanistan because of the meltwater resources that flow out of the country, towards the north. They conducted an intensive study in some parts of the Wakhan area (Haritashya 
et al. 2009). They carried out stereo-aerial photography covering one-third of the northern part of Afghanistan (Shroder 1980, 1989). In 1974, they began to prepare a glacier inventory of Afghanistan using incomplete sets of small-scale topographic maps derived from the aerial photographs taken in 1958-1959.

The recent development in RS and GIS techniques offer great potential for mapping and monitoring glaciers and glacier lakes on a larger scale and in shorter time periods (Paul et al. 2002; Bhambri and Bolch 2009; Bolch et al. 2010). These techniques enable automated image analysis, thereby reducing the time and cost to analyze the changes during various time periods. They also allow for geodetic surveys of individual and the entire river basin system.

In 2014, a team from Global Land Ice Measurements from Space (GLIMS) published a book on glacier studies at the global scale, which also carries a separate chapter on the study of glaciers using remote sensing in Afghanistan and Pakistan. This study, using various satellite images, reported the retreat of glaciers in Afghanistan, but could not come up with a digital data set of glacial changes for the whole of Afghanistan. In 2011, ICIMOD published a report on the status of glaciers in the HKH region, which also covers the glaciers in Afghanistan. However, the report does not cover the glacial area changes in Afghanistan; it provides only one-time data. Hence, the present study was initiated to prepare a database on the changes in glacier and glacier lakes in Afghanistan; this database is based on RS and GIS tools and techniques.

\subsection{Implementation}

The study adopted a semi-automatic method using an object-based image classification (OBIC) (Bajracharya and Shrestha 2011; Bajracharya et al. 2014a, 2018), to prepare the clean-ice (CI) and debris-covered (DC) glacier as a separate entity. For consistency, the same approach of mapping was applied for glacial lakes with

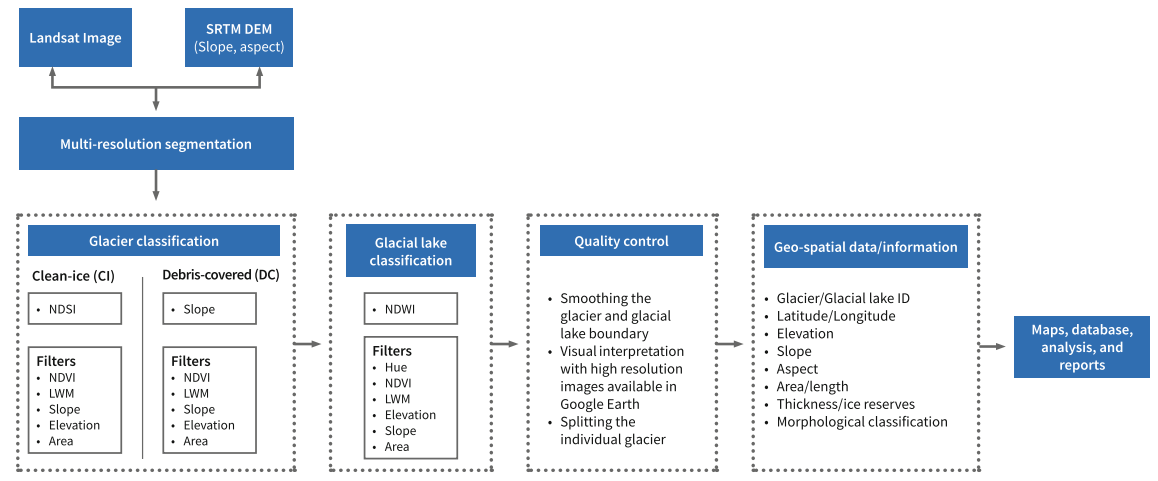

Fig. 11.1 Detailed methodology of mapping glaciers and glacial lakes 
the images used for glacier mapping (Fig. 11.1). The overall process of mapping consisted of separate algorithms for CI and DC glaciers as also for glacial lakes but with some manual intervention. The detailed multistage process of mapping glaciers and glacial lakes is summarized in Fig. 11.1.

The study used a series of Landsat (TM, ETM+, and OLI) images which are freely accessible and have a long historical record from 1980s. However, throughout the study area, due to topographic and climatic variability, it was difficult to get ideal images without cloud cover and least snow cover during the same time period. So, the images were selected with a one-year buffer of the representative year-for example, Landsat images from 2014 to 2016 were considered for mapping to represent the year 2015.

The classification of multispectral images, combined with the digital elevation model (DEM), was processed in the eCognition software. At first, the Landsat images of 2015 were used to prepare the status of glaciers and glacial lakes of Afghanistan. In this process, the image was segmented using multi-resolution segmentation mechanism which creates the image objects based upon spectral reflectance, shape, texture, and the relation to neighboring objects. These image objects were then classified based on spectral and spatial characteristics. Separate algorithms were used for mapping CI and DC glaciers and for glacial lakes. The CI part of the glaciers was mapped using the Normalized Difference Snow Index (NDSI); however, here it has to be noted that the threshold value of NDSI also captures the snow cover and other features such as shadows and waterbodies. These misclassified features were then eliminated by using various filters. Similarly, the DC part of the glaciers was mapped using the slope from the remaining unclassified objects, and various filters were used to eliminate the misclassified features (Fig. 11.1). For glacial lakes, the Normalized Difference Water Index (NDWI) was used to map the lake boundary. Sometimes, ice cliffs and walls of supra-glacial lakes are misclassified as glacial lakes, which were corrected by using various filters like Hue, Normalized Difference Vegetative Index (NDVI), and Land and Water Mask (LWM) (Fig. 11.1). The final output of the image classification was exported as vector data sets. The minor visual corrections, as well as quality checks and generation of parameters for the glaciers and glacial lakes, were conducted in the GIS environment. The other time data sets from the years 1990, 2000, and 2010 were generated by manually editing the 2015 data overlaying on the respective images of those three years. For higher accuracy and data quality, the results were further refined manually by backdropping the respective Landsat images and cross-checking on the available high-resolution images in Google Earth. 


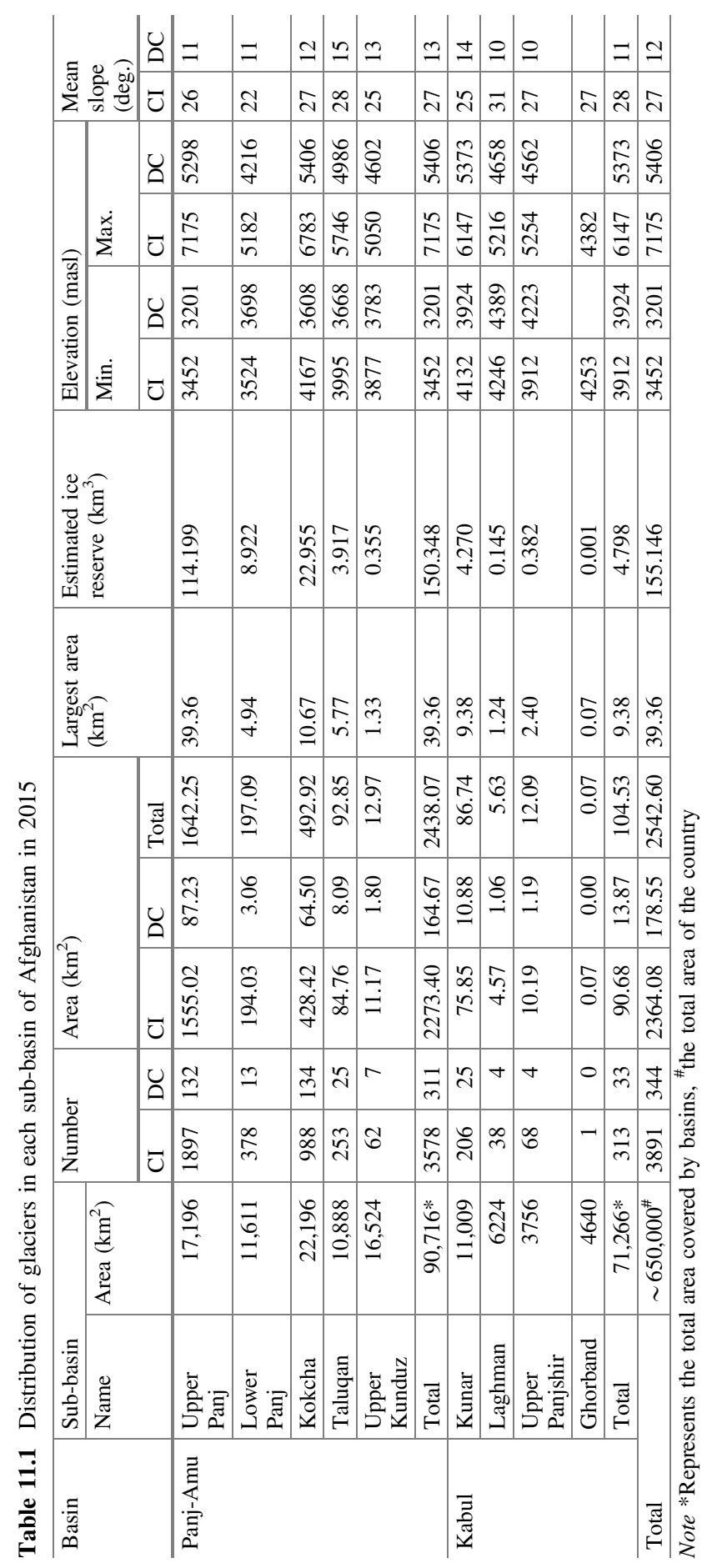




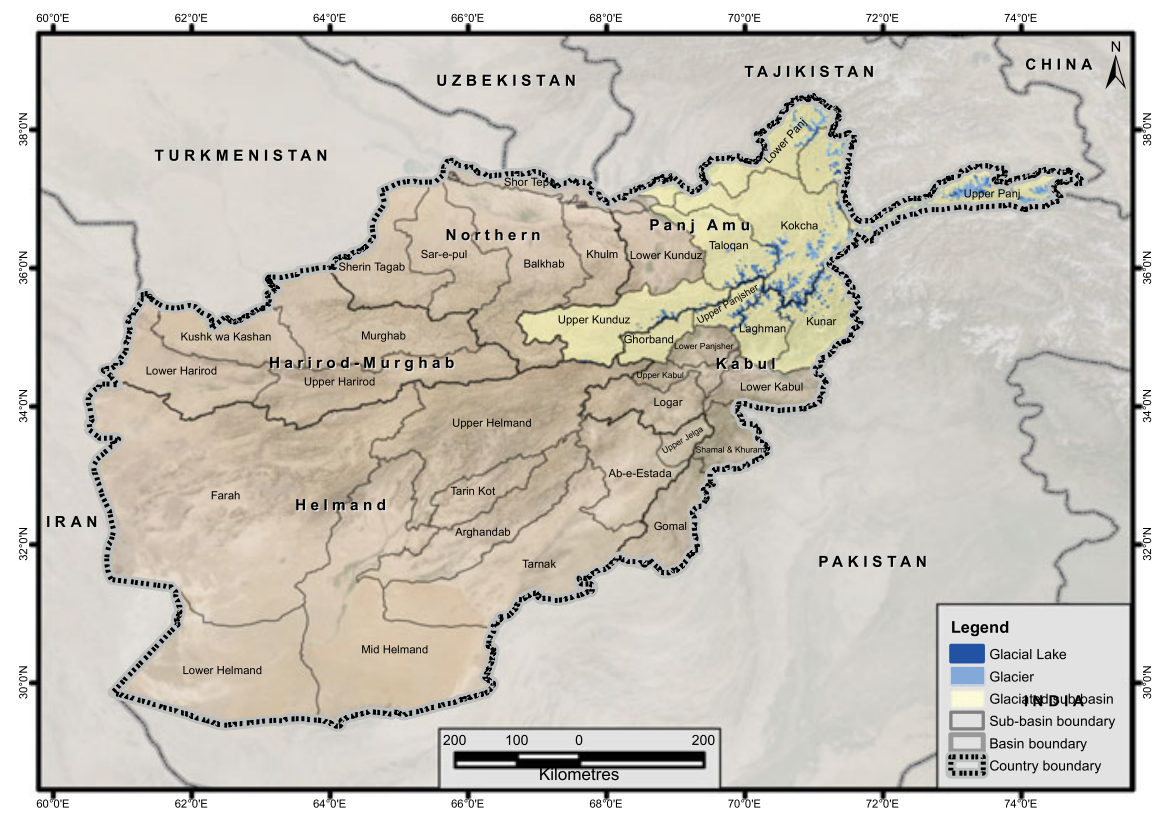

Fig. 11.2 Distribution of glaciers and glacial lakes in Afghanistan

\subsection{Results}

\subsubsection{Status of Glaciers and Its Changes}

Based on the Landsat images of 2015, altogether, 3891 glaciers were mapped, spanning an area of $2543 \mathrm{~km}^{2}$ (Table 11.1). The table shows that the glacial area covers about $0.4 \%$ of the total land area. Among the five river basins in Afghanistan, two major river basins-Panj-Amu and Kabul-consist of glaciers; while Panj-Amu accounts for $92 \%$ of the glacier area, the Kabul basin accounts for the rest $8 \%$ (Fig. 11.2). The Upper Panj sub-basin of the Panj-Amu River Basin consists of the highest concentration of glaciers, which is almost $65 \%$ of the total glacial area in the country. The largest glacier, with an area of $39.36 \mathrm{~km}^{2}$, also lies in the Upper Panj sub-basin at the narrowest part of the entrance to the Wakhan Corridor. The glaciers are distributed along elevations of 3200-7175 masl. The highest and lowest glaciers are in the Upper Panj sub-basin. And the highest concentration of glacial area is at 4500-5500 masl, covering about $78 \%$ of the total glacial area.

Most of the glaciers are mountain or valley glaciers of cirque or simple basin morphological type. Some larger valley glaciers are of the compound basin types. CI and DC are the two main parts of a basin glacier, be it mountain or valley glacier. Almost $9 \%$ of the glaciers in the country have the debris-covered part, 


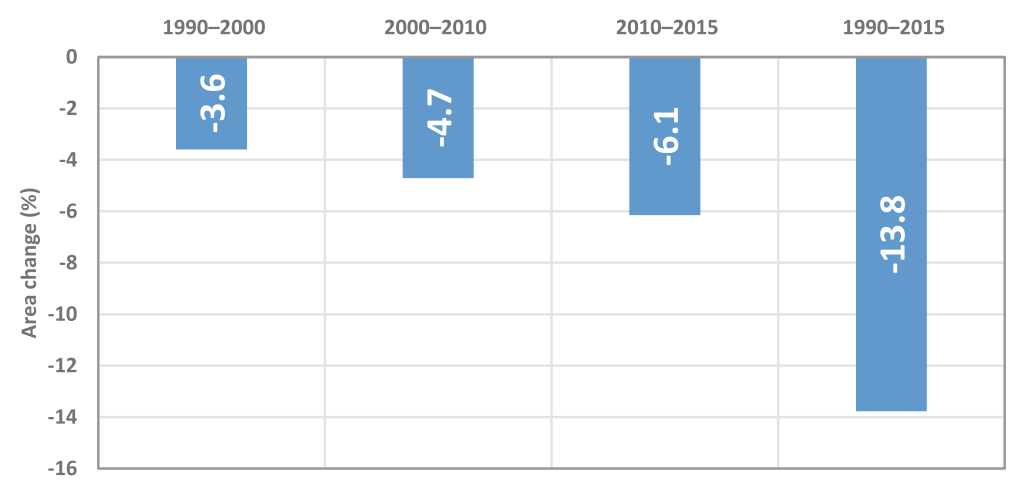

Fig. 11.3 Percentage of glacial area changes in Afghanistan

accounting for almost $7 \%$ of the total glacial area in the country. The number and area-wise distribution of the DC glaciers are higher in the Upper Panj and Kokcha sub-basins of the Panj-Amu River Basin. The average slope and elevation distribution of the DC part is lower than the CI part of glaciers.

The glacier change database of the years 1990, 2000, 2010, and 2015 shows that $13.8 \%$ of the glacial area was lost within this 25 -year period (Fig. 11.3). The rate of area loss was $3.6 \%$ between 1990 and 2000; 4.7\% between 2000 and 2010; and 2$7 \%$ from 1990 to 2000 . But this rate increased to $4-12 \%$ from 2000 to 2010 in most of the sub-basins. The area loss was about $6.1 \%$ in the five years from 2010 to 2015. This indicates that the area-loss percentage has been higher in recent decades.

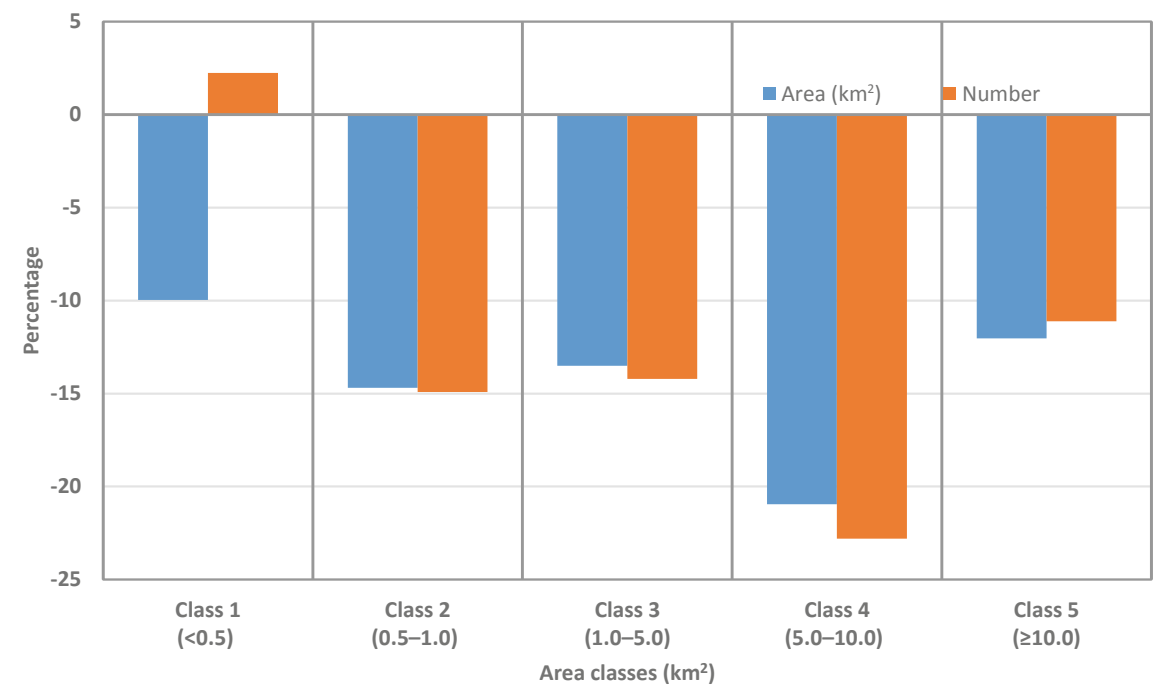

Fig. 11.4 Number and change percentage in each area size class from 1990 to 2015 


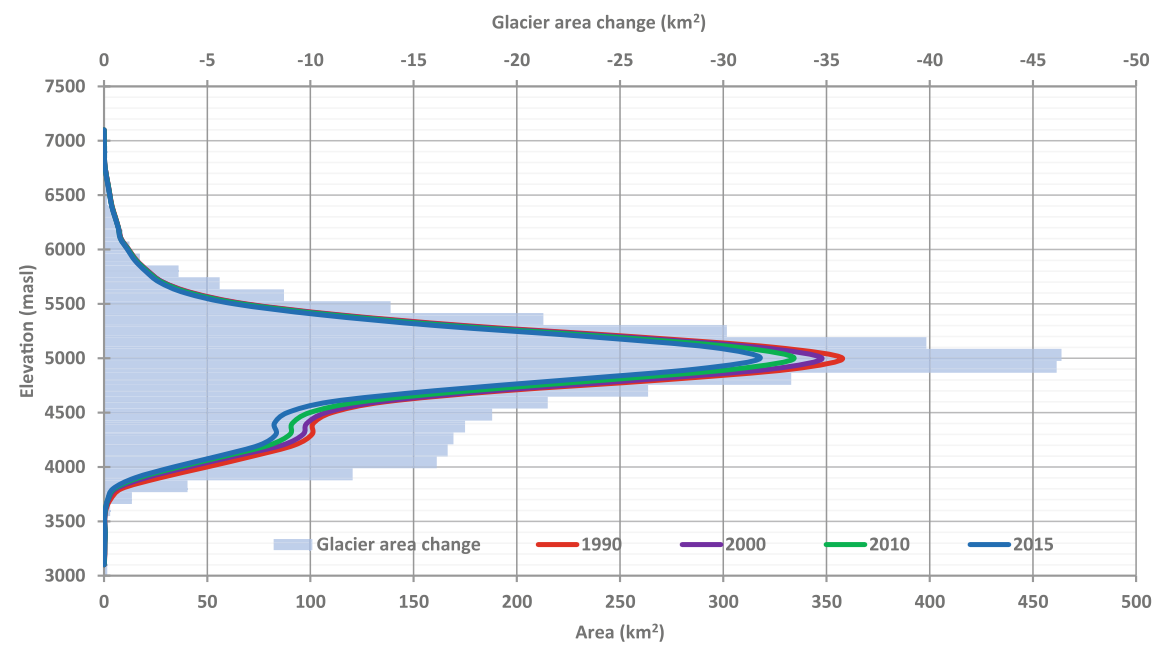

Fig. 11.5 Distribution of glacial area and changes in area from 1990 to 2015 at 100 m elevation zone

The study covered all the glaciers of sizes greater than or equal to $0.02 \mathrm{~km}^{2}$. The glacial area size distribution of five classes is shown in Fig. 11.4, which demonstrates that the number of glaciers has decreased in 25 years except in the case of smaller ones. The area of the glaciers has also decreased in all size classes, with a higher percentage of decline among the larger ones. This indicates that the glaciers in Afghanistan are shrinking and retreating at a quick rate. And due to the shrinkage and fragmentation of the larger glaciers, the number of smaller ones has increased. At the same time, the smaller glaciers have also shrunk, with some of them shrinking to an area less than the threshold of $0.02 \mathrm{~km}^{2}$; besides, some of the smaller glaciers have disappeared altogether, leading to a reduction in the number of glaciers in Afghanistan.

In Fig. 11.5, the area-wise distribution of glaciers shows the variations in area loss at different elevations. The maximum area loss was at elevations from 4700 to 5200 masl. In 25 years, the largest glacial area loss was $47 \mathrm{~km}^{2}$ at elevations from 4900 to 5000. There have been no significant changes in the glacial areas above 5500 masl, whereas the glacial areas below 3200 masl have completely disappeared.

\subsubsection{Status of Glacial Lake and Its Changes}

Based on Landsat images, the current study mapped the glacial lakes of sizes greater than or equal to $0.003 \mathrm{~km}^{2}$. This study covered all the waterbodies that are situated proximal to present glaciers as well as those located in lowland areas that 
were formed by paleo-glaciation (Maharjan et al. 2018). These lakes were analyzed based on size, altitude, and morphological classification using the available SRTM DEM (Shuttle Radar Topography Mission-Digital Elevation Model) and high-resolution images from Google Earth. These lakes were classified into seven types based on their damming condition and morphological location: (a) moraine dammed - end moraine $(\mathrm{M}(\mathrm{e}))$, lateral moraine $(\mathrm{M}(\mathrm{l}))$, and other moraine dammed (M(o)); (b) ice-dammed - supra-glacial (I(s)) and dammed by valley glacier (I(v)); (c) bedrock dammed-cirque $(\mathrm{B}(\mathrm{c}))$ and other glacier erosional $(\mathrm{B}(\mathrm{o}))$; and (d) other dammed lakes $(\mathrm{O})$ — dammed by landslides, debris flow, etc. lying on glaciated valleys and fed by glaciers.

In total, 1942 glacial lakes, covering an area of almost $89 \mathrm{~km}^{2}$, were mapped via the Landsat images of 2015. The lakes are distributed within the two major river basins of the country-Panj Amu and Kabul. The Panj-Amu basin has the largest number of glacier lakes, around $64 \%$ of such lakes in the country, covering almost $74 \%$ of the total area covered by glacial lakes in Afghanistan (Table 11.2). The size of the lakes ranges from 0.003 to $14.63 \mathrm{~km}^{2}$, with a mean size of $0.5 \mathrm{~km}^{2}$. The majority of the lakes are smaller than $0.5 \mathrm{~km}^{2}$; only 10 lakes are larger than $0.5 \mathrm{~km}^{2}$ and most of these either other dammed or bedrock dammed lakes except two lakes are moraine dammed (Fig. 11.6). The smallest lakes (of size less than $0.02 \mathrm{~km}^{2}$ ) account for $52 \%$ (number $=1009$ ) of the total lakes in the country. More than $71 \%$ of the lakes are bedrock-dammed ones which are mostly formed on the erosional

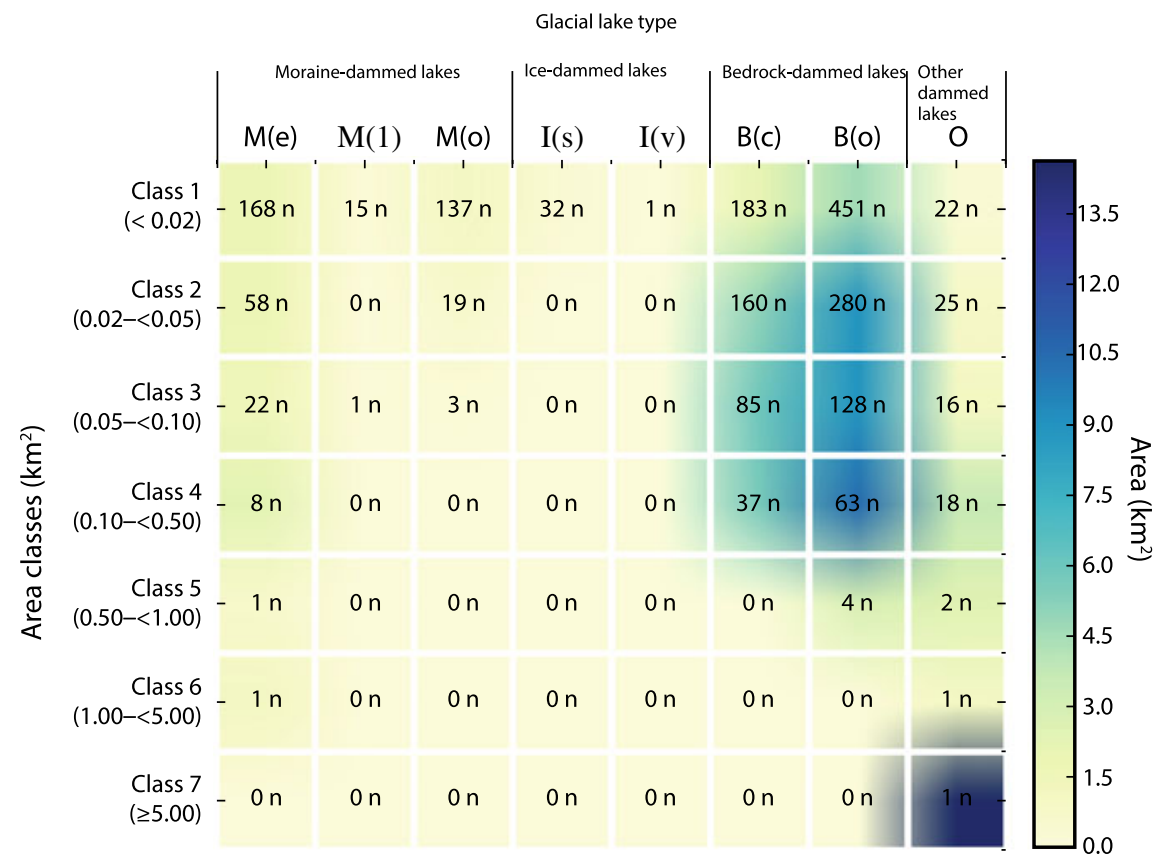

Fig. 11.6 Number and area-wise distribution at different size classes and types of glacial lakes 


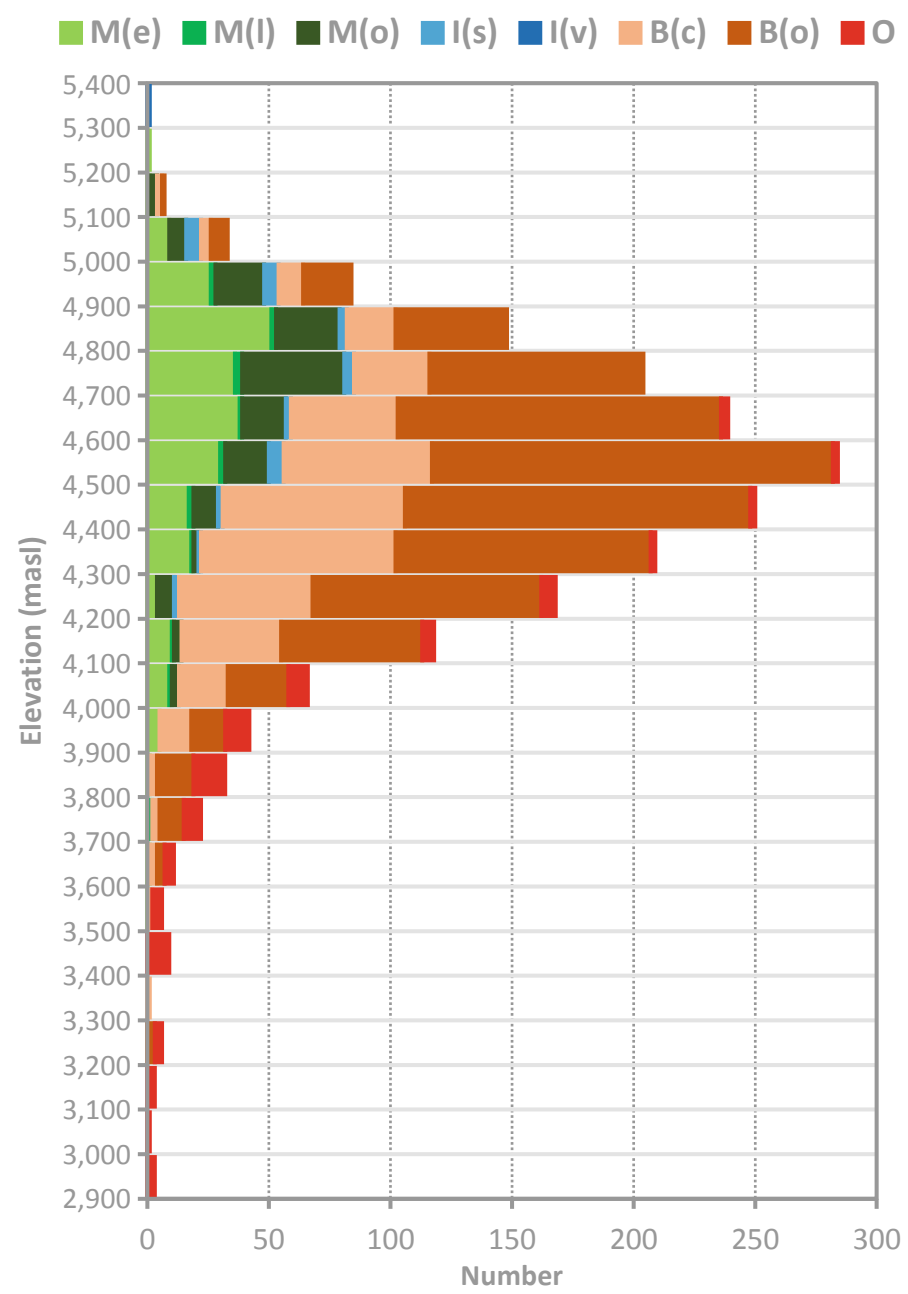

Fig. 11.7 Glacial lake distribution at 100 m elevation zone

surface of glaciers. The remaining $22.5 \%$ are moraine dammed and most of these (almost 17\%) are smaller (less than $0.02 \mathrm{~km}^{2}$ ) in size, and have an average size of $0.025 \mathrm{~km}^{2}$.

The altitudinal distribution of the glacial lakes ranges between 2900 and 5400 masl, with the largest number of lakes ( $83 \%$ of the total) situated within an elevation range of 4100-4900 masl (Fig. 11.7).

So, considering the formation of new lakes, the expansion of lakes, and even their disappearance, going by the data of the years 1990, 2000, 2010, and 2015, it emerges that the development and evolution of glacial lakes have been inconsistent. Overall, the change database shows increase in the number and area of the glacial 


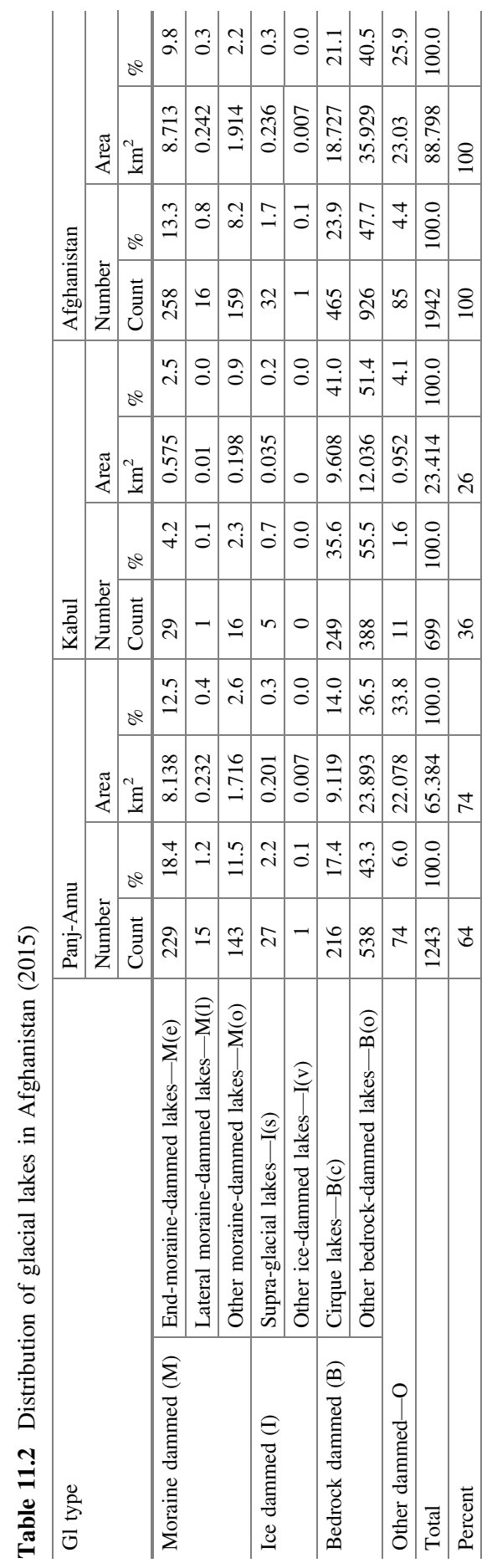




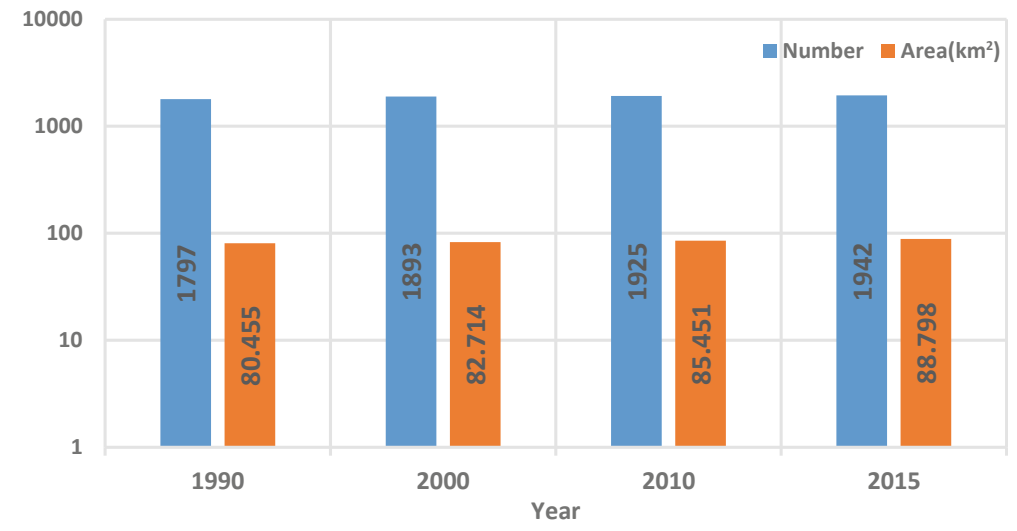

Fig. 11.8 Number and area of glacial lakes in four time periods from 1990 to 2015 in Afghanistan
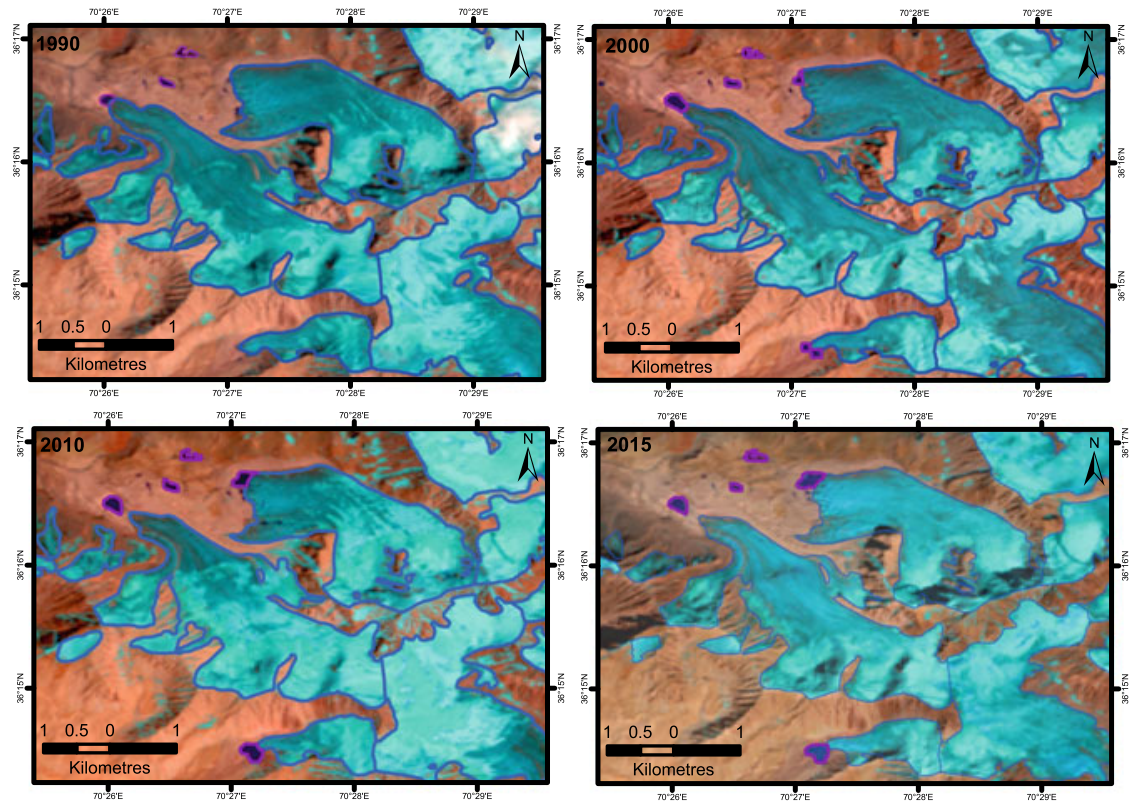

Fig. 11.9 The formation and expansion of glacial lakes; an example from the Taloqan sub-basin of the Panj-Amu River Basin

lakes. In the 25 -year period, the number has increased by $8 \%$ and the area by $10 \%$ (Fig. 11.8). The changes are inconsistent, as they depend on the type of lake and the elevation range. It's mostly the moraine dammed lakes that are in contact with glaciers which have expanded (Fig. 11.9). The expansion of these lakes is mostly towards the direction of glaciers, in the space left by the glacier retreat. New lakes 
were formed due to shrinking and melting of glaciers, which is indicated by the increase in the number of lakes of smaller size (less than $0.05 \mathrm{~km}^{2}$ ). And the comparatively higher rate of expansion took place among lakes with an area of 0.5 $0.5 \mathrm{~km}^{2}$. The number of moraine-dammed lakes increased in both decades 1990 2000 and 2000-2010, whereas the number of bedrock-dammed lakes and other lake types showed a decline. Mostly, the changes in lake size and the formation of new lakes are evident in the 4000-5100 masl elevation range, with the highest rate at the range of 4500-5100 masl. More than 6\% of the new lakes were formed from 1990 to 2015 within the $4500-5100$ masl elevation range, and they expanded by about $6.6 \%$.

\subsection{Institutional Collaboration}

The need for a comprehensive database on glaciers and glacial lakes in Afghanistan emerged in a number of consultations carried out with the stakeholders. However, instead of carrying out the task all by itself, SERVIR-HKH adopted the approach of co-development where NWARA was an equal partner in the implementation process. A team of six professionals was formed at NWARA, including two nominated by NWARA and four research associates supported by SERVIR-HKH. The team worked solely on the mapping application and were trained, guided, and supervised by the SERVIR-HKH staff at ICIMOD. The main objective of this approach was to enable NWARA to carry out such exercises independently by Afghan professionals in the future.

\subsubsection{Capacity Development}

The capacity development of Afghan professionals on glacier and glacial lake research has been one of the successful endeavors in SERVIR's institutional capacity-building initiative. The experts from ICIMOD provided several hands-on and on-the-job trainings to initiate the work. In the beginning, a general hands-on training program was organized at GDWR to foster a better understanding about glaciers and glacial lakes and to develop the participants' ability to generate and use data on their own for monitoring and assessing glaciers and glacial lakes in Afghanistan. Later, the team of six staff at NWARA was provided several on-the-job trainings for preparing the glacier and glacial lake database of Afghanistan (Fig. 11.10). The team proved successful in preparing the database and in developing a detailed analysis report; this was carried out under the direct supervision and with technical guidance from the experts at ICIMOD. Through this overall exercise, the team has developed the skills and confidence in applying RS and GIS techniques in the mapping, monitoring, and assessment of glaciers and glacial lakes. Then, the team members, as resource persons, organized several 


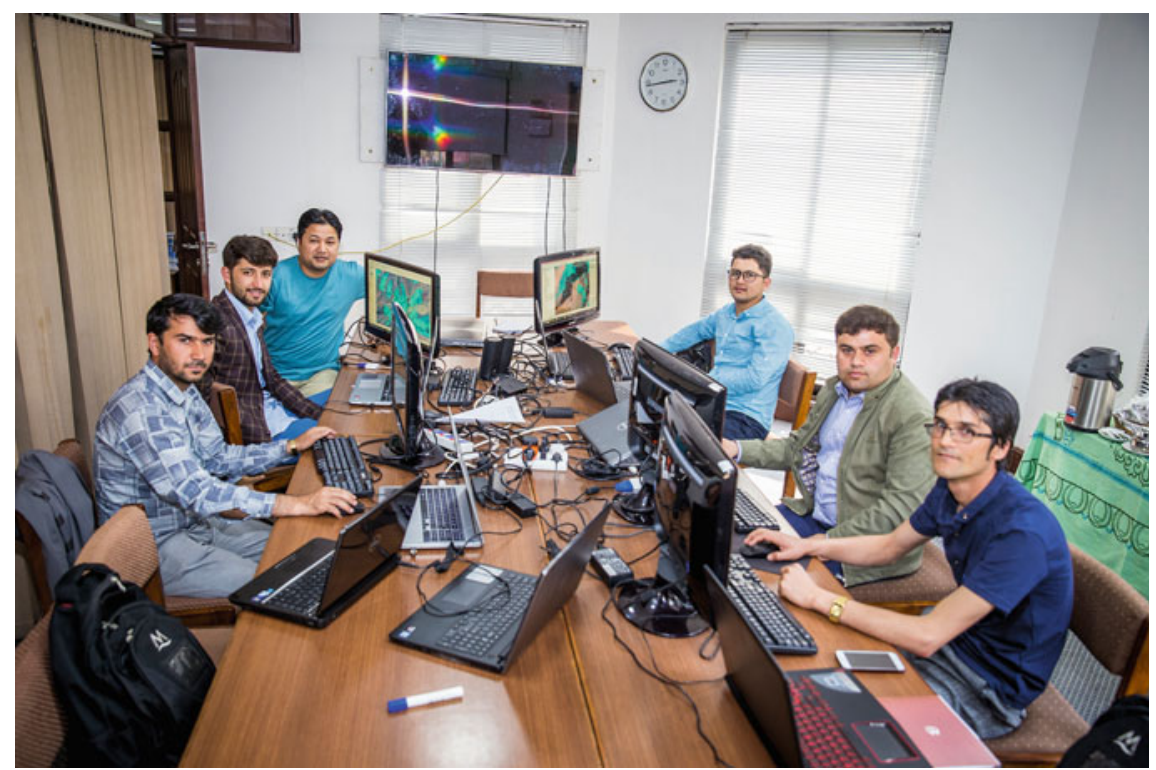

Fig. 11.10 On-the-job training at ICIMOD for the team preparing the glacier and glacial lake database. Photo by Jitendra Raj Bajracharya

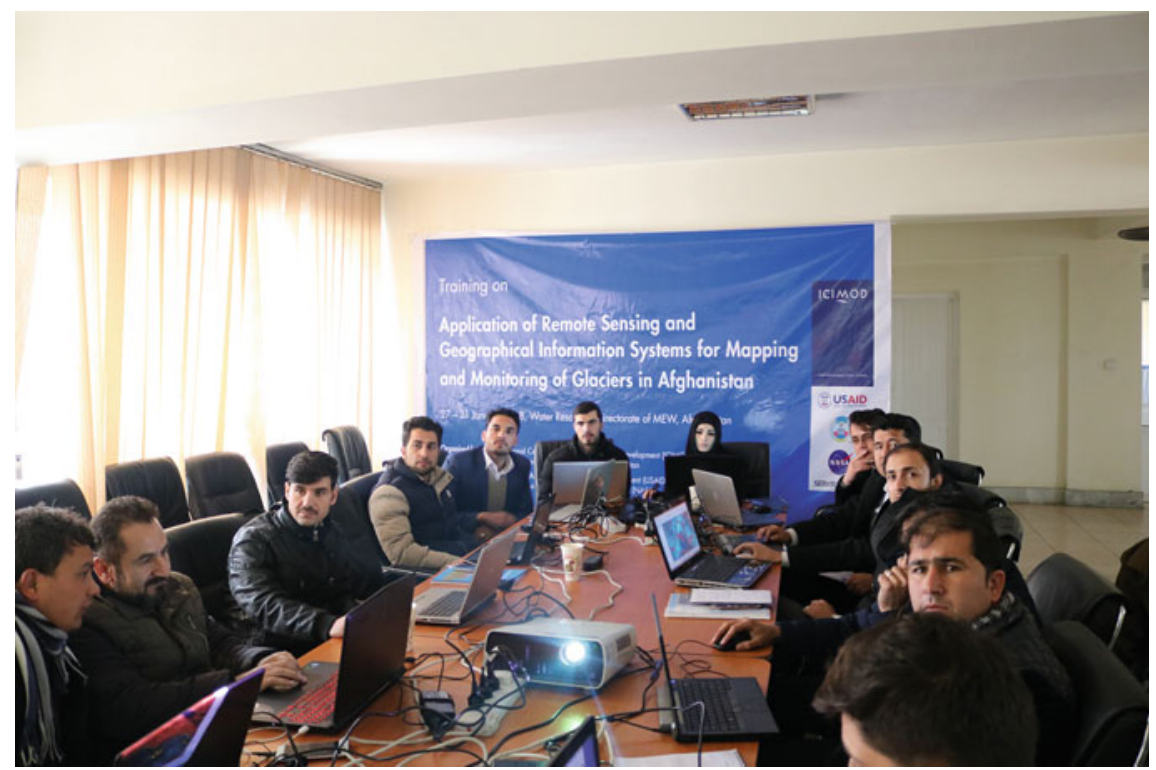

Fig. 11.11 The mapping team being provided training on glacier mapping and monitoring. Photo by Esmatullah Joya 
trainings for other professionals in NWARA, thus replicating the capacity-building efforts in a more sustainable way (Fig. 11.11).

\subsubsection{Dissemination}

The first comprehensive glacier database of Afghanistan was launched at a dissemination workshop (Fig. 11.12) on 2 July 2018, and Glacial lake database was launched on 23 Nov 2020 which were organized at the NWARA office in Kabul. An online application was also launched during the occasion which provides access to the database and an interactive visualization of the glaciers and the changes over time. The general public, students, and researchers can also access glacier and glacial lake data for all periods through the Regional Database System (RDS), ICIMOD website (rds.icimod.org).

The professionals and policymakers at the dissemination workshop emphasized the importance of the glacier database and portal for better management of water resources in Afghanistan. The discussions also touched upon the following: the need to validate data through field surveys; the use of high-resolution imagery in the case of some selected glaciers for further detailed study on glacier melts and mass balances; and the installation of automatic weather stations and hydro-climatic stations in some of the selected glaciers so that there would be more in-depth understanding about glaciers as well as more realistic information on the

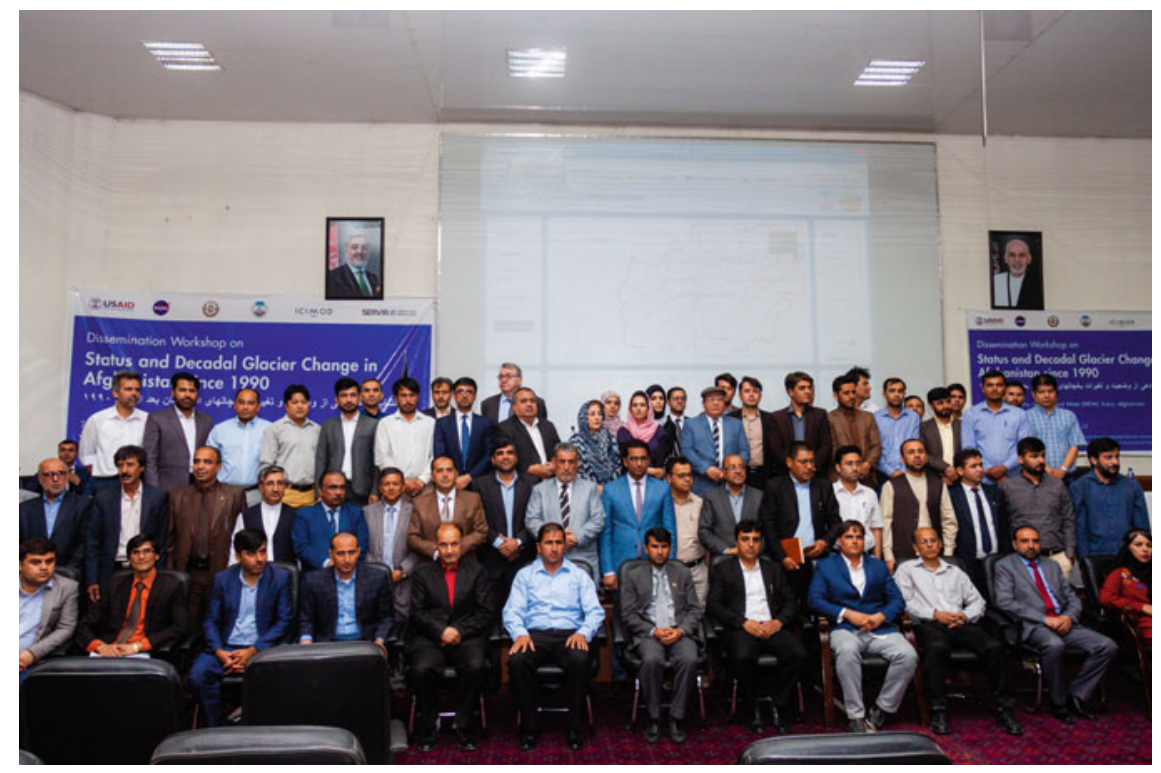

Fig. 11.12 Participants of the dissemination workshop held at NWARA on 2 July 2018. Photo by Utsav Maden 
glacier-melting processes. The professionals also called for better coordination among all the stakeholders concerned, including academicians, to enable longer-time monitoring of the glaciers. Further, they sought the support of all the relevant organizations to ensure the sustainability of the database and its efficient use.

\subsection{Lessons Learnt}

The main aim of SERVIR-HKH was to build the capacity of the national professionals of Afghanistan on the application of EO and GIS technology for glacier and glacial lake mapping and monitoring while generating a national database. Since the engaged professionals did not have a previous background of working on EO and glacier mapping, the initial trainings were quite taxing. Moreover, the experts at ICIMOD had to guide and supervise the team in Kabul remotely which was quite challenging and required many iterations for the finalization of the database.

There were also technical challenges in the mapping processes. The NDSI and NDWI indices are effective in mapping CI glaciers and glacial lakes, but not for mapping larger areas as that involves hindrances such as shadows, clouds, seasonal snow, turbid/frozen pro-glacial lakes, and some permanent snow cover. In this context, the algorithms do not work properly in the case of the ice in the shadow areas and for turbid or frozen pro-glacial lakes. These regions need to be checked carefully and need some manual correction. But there exists no best algorithm for DC glacier mapping which can be applied for the larger regions without some manual corrections of the boundaries and terminus. The smooth textural surface of the debris-covered part compared to other regions in the HKH added more challenges in accurately delineating its boundary and terminus. The textural variation between the DC glaciers and its surrounding moraine and barred rock areas was difficult to differentiate through the Landsat images. Also, cross-checking of the higher-resolution images in the Google Earth environment was not possible due to the low quality of the images. Hence, the manual correction of the debris-covered part required special attention.

\subsection{Way Forward}

Based on Landsat images, the study provides a comprehensive picture of the status and changes in glaciers and glacial lakes over the period of a quarter century-from 1990 to 2015. This is a big achievement for Afghanistan. The generated data can also be utilized in monitoring and understanding the dynamics of glacier and glacial lakes in the future and for other purposes such as for modeling the availability of water resources, glacial hazard prediction, and to know more about the impacts of climate change on glaciers. 
Apart from this information, the project also strengthened cooperation and collaboration with local partners and enhanced their knowledge on the mapping and monitoring of glaciers and glacial lakes. The trained human resources in this area of mapping and monitoring are indeed a great asset to the country and can contribute significantly to the vital area of water management. Now the system should be further developed to enable regular monitoring, at least at five- or ten-year intervals, so that the relevant agencies are up to date about the trends in glacial changes. More investigations are also required in spheres such as geodetic glacier mass changes, glacio-hydrological models, and glacier and snowmelt modeling. This will come in handy in important catchment areas and give a clearer picture on the availability of water resources, the risks of glacial hazards, and on the overall changes in the glacial environment. It can also be utilized to identify some representative glaciers for long-term in situ monitoring.

Since Afghanistan is an arid and semi-arid country, irrigation is essential for food production. Any in-depth information on the country's glaciers and their run-off would be of critical value to establish a reliable and equitable irrigation system; and this would have positive impacts on agricultural productivity, food security, and income, while also reducing the vulnerability of farmers to droughts.

Most of Afghanistan's rivers have hydropower potential. It is estimated that the country can generate 23,000 MW of hydropower (Ahmadzai and McKinna 2018). In such a scenario, a scientific documentation of the present and periodic changes in glacial lakes would be valuable when it comes to constructing hydropower plants upstream, near glacial lakes, and in identifying the risks involved in building a particular plant.

Coming to GLOFs, the time-series glacial lake data can be utilized to identify the potentially dangerous glacier lakes in the country and to list the lakes in terms of their danger quotient. A GLOF risk reduction strategy should be established not only to reduce risk but also to increase the resilience of the vulnerable communities. A policy should also be developed to strengthen national and institutional capacities in the establishment of GLOF-resilient development pathways.

\section{References}

Afghanistan Times (2018) Flash floods kill 10 in Panjshir, July 12, 2018, latest updates, http:// www.afghanistantimes.af/flash-floods-kill-10-panjshir/

Ahmadzai S, McKinna A (2018) Afghanistan electrical energy and trans-boundary water systems analyses: challenges and opportunities. Energy Rep 4:435-469

Aich V, Akhundzadah N, Knuerr A, Khoshbeen A, Hattermann F, Paeth H, Scanlon A, ..., Paton E (2017) Climate change in afghanistan deduced from reanalysis and coordinated regional climate downscaling experiment (CORDEX)—South Asia Simulations. Climate 5:38, https://doi.org/10.3390/cli5020038

Allen SK, Rastner P, Arora M, Huggel C, Stoffel M (2015) Lake outburst and debris flow disaster at Kedarnath, June 2013: hydrometeorological triggering and topographic predisposition. Landslides 13(6):1479-1491. https://doi.org/10.1007/s10346-015-0584-3 
Bajracharya SR, Maharjan SB, Shrestha F (2018) Training manual on Application of remote sensing and geographic information systems for mapping and monitoring of glaciers using eCognition software. ICIMOD, Kathmandu

Bajracharya SR, Maharjan SB, Shrestha F, Bajracharya OR, Baidya S (2014a) Glacier status in Nepal and decadal change from 1980 to 2010 based on landsat data. ICIMOD, Kathmandu

Bajracharya SR, Maharjan SB, Shrestha F (2014b) The status and decadal change of glaciers in Bhutan from 1980s to 2010 based on the satellite data. Ann Glaciol 55(66):159-166. https:// doi.org/10.3189/2014aog66a125

Bajracharya SR, Shrestha B (eds) (2011) The status of glaciers in the Hindu Kush-Himalayan region. ICIMOD, Kathmandu, http://lib.icimod.org/record/9419

Bajracharya SR, Mool PK, Shrestha BR (2007) Impact of climate change on Himalayan glaciers and glacial lakes-case studies on GLOF and associated hazards in Nepal and Bhutan. ICIMOD, Kathmandu

Bhambri R, Bolch T (2009) Glacier mapping: a review with special reference to the Indian Himalayas. Prog Phys Geogr 33(5):672-704

Bolch T, Menounos B, Wheate RD (2010) Landsat-based inventory of glaciers in western Canada, 1985-2005. Remote Sens Environ 114(1):127-137

Braslau D (1972) The glaciers of Keshnikhan. In: Gratzl K (ed) Hindukusch-Österreichische Forschungsexpedition in den Wakhan 1970. Akademische Druck-u, Verlagsanstalt, Graz, Austria, pp 112-116

Breckle SW, Frey W (1976a) Die hochsten Berge im Zentralen Hindukusch [The highest mountains in the central Hindu Kush]. Afghanistan J 3(3):91-94

Breckle SW, Frey W (1976b) Beobachtungen zur heutigen Vergletscherung der Hauptkette des Zentralen Hindukusch [Observations of the present-day glacierization of the principal mountain ranges in the central Hindu Kush]. Afghanistan J 3(3):95-100

FloodList (2018) Afghanistan-deadly floods wreak Havoc in Panjshir Province. Flood List News in Asia, http://floodlist.com/asia/afghanistan-floods-panjshir-province-july-2018

Gardent M, Rabatel A, Dedieu JP, Deline P (2014) Multitemporal glacier inventory of the French Alps from the late 1960s to the late 2000s. Glob Planet Chang 120:24-37. https://doi.org/10. 1016/j.gloplacha.2014.05.004

Gilbert O, Jamieson D, Lister H, Pendlington A (1969) Regime of an Afghan glacier. J Gkciol 8 (52):51-65

Grotzbach E (1964) Munchner Hindukusch-Kundfahrt 1963. Die Erde, Bd. 95, Ht. 4, 29:1-98

Gurung DR, Khanal NR, Bajracharya SR, Tsering K, Joshi S, Tshering P, Chhetri LK, Lotay Y, Penjor T (2017) Lemthang Tsho glacial Lake outburst flood (GLOF) in Bhutan: cause and impact. Geoenviron Disasters 4:4-17. https://doi.org/10.1186/s40677-017-0080-2

Haritashya UK, Bishop MP, Shroder JF, Bush ABG, Bulley HNN (2009) Space-based assessment of glacier fluctuations in the Wakhan Pamir, Afghanistan. Climatic Change 94(1-2):5-18

IPCC (2013) The physical basis: contribution of working group I to the fifth assessment report of the intergovernmental panel on climate change. IPCC, Cambridge, UK, New York, NY, USA

Maharjan SB, Mool PK, Lizong W, Xiao G, Shrestha F, Shrestha RB, Khanal NR, Bajracharya SR, Joshi S, Shahi S, Baral P (2018) The status of glacial lakes in the Hindu Kush Himalaya. ICIMOD Research Report 2018/1. ICIMOD, Kathmandu

Maharjan SB (2018) Assessment of Peshghor flood in Khenj district, Panjshir Province, Afghanistan, rapid assessment report submitted to MEW, ICIMOD. Online: story map https:// www.arcgis.com/apps/MapJournal/index.html?appid=e842d20e0fb74abea6d57edc785b3a78

Marshall SJ (2014) Meltwater runoff from Haig Glacier, Canadian rocky mountains, 2002-2013. Hydrol Earth Syst Sci Discuss 11:8355-8407. https://doi.org/10.5194/hessd-11-8355-2014

Mernild SH, Lipscomb WH, Bahr DB, Radić V, Zemp M (2013) Global glacier changes: a revised assessment of committed mass losses and sampling uncertainties. Cryosphere 7(5):1565-1577. https://doi.org/10.5194/tc-7-1565-2013

Nie Y, Liu Q, Nie Y, Sheng Y, Song C, Liu L, Zhang Y, ..., Liu S (2017) A regional-scale assessment of Himalayan glacial lake changes using satellite observations from 1990 to 2015. Remote Sens Environ 189:1-13. http://dx.doi.org/10.1016/j.rse.2016.11.008 
Prasad AK, Elaskary HM, Asrar GR, Kafatos M, Jaswal A (2011) Melting of major glaciers in Himalaya: role of desert dust and anthropogenic aerosols. In: Carayannis E (ed) Planet earth 2011_global warming challenges and opportunities for policy and practice. https://doi.org/10. $5772 / 902$

Patzelt G (1978) Gletscherkundliche Untersuchlungen im 'Grossen Pamir'. In: Grancy R, Kostka R (eds) Grosser Pamir. Akademische Druck-u, Graz, pp 131-149

Paul F, Kaab A, Maisch M, Kellenberger T, Haeberli W (2002) The new remote-sensing-derived Swiss glacier inventory: I. methods. Ann Glaciol 34:355-361. https://doi.org/10.3189/ 172756402781817941

Shroder JF Jr (1980) Special problems of glacial inventory in Afghanistan. Hydrol Sc Bull 126:142-147, World Glacier Inventory Proceedings, Reideralp Workshop, September 1978 (IAHS-AISH)

Shroder JF Jr (1989) Glacierized areas of Afghanistan. In: Haeberli W, Bosch H, Scherler K, Ostrem G, Wallen CC (eds) World glacier inventory, status 1988. IAHS (ICSI)UNEP-UNESCO, Teufen, C39-C40, C346-C353

Song C, Sheng Y, Madson A, Wang J, Ke L, Nie Y (2017) Heterogeneous glacial lake changes and links of lake expansions to the rapid thinning of adjacent glacier termini in the Himalayas. Geomorphology 280:30-38. https://doi.org/10.1016/j.geomorph.2016.12.002

Wester P, Mishra A, Mujherji A, Shrestha AB (eds) (2019) The Hindu Kush Himalaya assessment - mountains, climate change, sustainability and people. Springer, Switzerland AG, Cham

Zemp M, Amstrong R, Gärnter-Roer I, Haeberli W, Hoelzle M, Kääb A, Kargel JS, Khalsa SJS, Leonard GJ, Paul F, Raup BH (2014) Introduction: global glacier monitoring - a long-term task integrating in situ observations and remote sensing. In: Kargel JS, Leonard GJ, Bishop MP, Kääb A, Raup BH (eds) Global land ice measurements from space. Springer, Berlin

Open Access This chapter is licensed under the terms of the Creative Commons Attribution 4.0 International License (http://creativecommons.org/licenses/by/4.0/), which permits use, sharing, adaptation, distribution and reproduction in any medium or format, as long as you give appropriate credit to the original author(s) and the source, provide a link to the Creative Commons license and indicate if changes were made.

The images or other third party material in this chapter are included in the chapter's Creative Commons license, unless indicated otherwise in a credit line to the material. If material is not included in the chapter's Creative Commons license and your intended use is not permitted by statutory regulation or exceeds the permitted use, you will need to obtain permission directly from the copyright holder. 